\title{
DOES ZAKAT MATTER IN THE MIDST OF A PANDEMIC?: A CASE STUDY
}

\author{
Muhammad Soleh Nurzaman ${ }^{\mathbf{1}}$ and Nadia Putri ${ }^{2}$ \\ ${ }^{1,2}$ University of Indonesia \\ ${ }^{1,2}$ Jl. Salemba Raya, Kenari, Senen, Jakarta Pusat \\ Email: ${ }^{2}$ nadia.putri93@ui.ac.id
}

\begin{abstract}
ABSTRAK
Berbagai permasalahan muncul setelah merebaknya pandemi covid-19. Tidak hanya yang berkaitan dengan dunia kesehatan namun juga ekonomi dan pendidikan. Hal ini memicu angka jumlah pengangguran di Indonesia yang menjadi sangat mengkhawatirkan. Diperlukan adanya keahlian tambahan untuk bertahan di tengah pandemi yang mengancam. Adanya dana zakat yang dapat dimaksimalkan sebagai alat pertahanan hendaknya digunakan untuk mengatasi permasalahan yang dimulai dari segi pendidikan. Penelitian ini bertujuan untuk melihat dampak dari zakat produktif yang digunakan untuk membiayai Pesantren Teknologi Informasi dan Komunikasi (PeTIK) sebagai program pendidikan berbasis teknologi. Menggunakan metode SROI hasil menunjukkan bahwa rasio PeTIK berada di angka 1.7 yang berarti bahwa terdapat dampak sebesar Rp. 1.7 dari setiap Rp. 1 yang diinvestasikan. Dampak yang dihasilkan PeTIK antara lain peluang mendapatkan beasiswa S1 bagi alumni, adanya peningkatan pendidikan, peningkatan penghasilan, peluang lowongan kerja, serta penurunan tingkat kemiskinan. Hal ini mengindikasikan bahwa PeTIK dapat menjadi solusi atas permasalahan yang timbul akibat covid-19.
\end{abstract}

Kata kunci: Zakat, SROI, Pendidikan berbasis teknologi

\begin{abstract}
Various problems have arisen after the outbreak of the COVID-19 pandemic. Not only affecting the health care system, but also the economy and education. This triggers the numbers of unemployment in Indonesia. Additional skills are needed to survive in the midst of a threatening pandemic. The existence of zakat funds that can be maximized as a means of defense should be used to overcome problems starting from the aspect of education. This study aims to see the impact of productive zakat which become the source of funds for Pesantren Teknologi Informasi dan Komunikasi (PeTIK) as a technology-based education program. Using the Social Return on Investment (SROI) method the results show that the PeTIK ratio is at 1.7 , which means that there is an impact of Rp. 1.7 of every Rp. 1 invested. The impacts created are undergraduate scholarship programs for alumni, an increase in education, income, employment opportunities, and children's education, and also a decrease in poverty levels. This indicates that PeTIK is one of the solutions to problems that arise due to COVID-19.
\end{abstract}

Keywords: Zakat, SROI, technology-based education 


\section{INTRODUCTION}

Indonesia has entered the second year of the pandemic yet new cases seem to keep surging. Before the pandemic, one of the problems experienced by Indonesia was unemployment. Quoted from CNN Indonesia, the number of unemployed in Indonesia according to Badan Pusat Statistik (BPS), an Indonesian Central Statistics Agency, as of February 2019 is 6,816,840. Of this number, the highest number is occupied by high school graduates which reached 1,680,794 (CNN Indonesia, 2020).

After the pandemic, the unemployment rate continued to rise. The Jakarta Post reported the BPS statement that unemployment is currently the highest number since 2011 with the unemployment rate standing at $7.07 \%$ in August 2020 (Nurhayati, 2020). Moreover, the growth of digitalization might trigger the dislocation of young workers (Blustein et al., 2020). The same research also stated that one of the things that might help the problems of unemployment is involving young people to improve their capacities and knowledge.

Providing free access to education for the unfortunate youth has been done for many years by many Non-Governmental Organizations. Some of the previous researches are The Measurement of Social Value Impact of ZISWAF Using Social Return on Investment Model (SROI) at SMART EKSELENSIA Indonesia by (Nusapati, 2020); Impact Assessment of The BAZNAS (Badan Amil Zakat Nasional/National Zakat Agency) Scholarship Program with The Social Return on Investment Approach in Several Indonesian Universities by (Hanik, Maharani, \& Fadhil, 2020); and Multiplier Effect of Zakat: Case Study in Tello Island, South Nias, Indonesia on National Amil Zakat Agency Education Program by (Sudrajat \& Aisyah, 2017).

YBM PLN (a private national zakat agency) then initiated its own educational institution called Pesantren Teknologi and Informasi also known as PeTIK. Highlighting the fact that PeTIK is the only free educational institutions that focuses on the technology and information, might also prove that it is one of the solutions needed for the problems faced by Indonesia in the midst of the pandemic. But is the problem of unemployment can be solved so easily while there is no concrete study indicating PeTIK can be one of the solutions?

Using SROI as the methodology, the research is the first one conducted on PeTIK since the establishment 9 years ago. The research also hopes to contribute to one of the agendas initiated by Blustein et al., (2020) which is developing a framework for an evidence-based intervention for unemployed individuals and aims to find out the impacts PeTIK has brought as an organization focusing on youth education in technology and information. 


\section{LITERATURE REVIEW}

This chapter will include the related literature in this research such as productive zakat, pandemic, technology-based education, and also SROI analysis.

\subsection{PRODUCTIVE ZAKAT}

Productive zakat is the kind of zakat which distributed for productive distribution activities. The expected result of productive zakat is that it would make the recipient earn a continuous income which will lead them to become financially independent (Widiastuti \& Rosyidi, 2015).

Experts also have opinions about productive zakat. Imam Gazali stated that the poor should be given a share of the zakat funds which can be used to buy land which then the proceeds from the land can meet the needs of mustahik for life. In addition, Yusuf Qardawi also stated that Islamic countries are allowed to build factories, companies, and others, which then ownership can be given to the poor, in part or in whole. Aiming that the business owned can generate profits and can be a source of income for mustahik (Fasiha, 2017).

According to Shidiq (2017), the prospect of productive zakat is very promising if it is managed properly and professionally. Efforts can be made to achieve the target of the prospect of productive zakat itself, namely by fulfilling the need for reliable HR (Human Resources) by holding training or training.

In this research, productive zakat was used as the source of funds to run PeTIK as a program that provides technology-based education for unfortunate youth across the nation.

\subsection{TECHNOLOGY-BASED EDUCATION}

The existence of modern technology applied in the teaching and learning system makes the knowledge transfer process more effective and easier. Communication via mobile phones, visiting certain learning sites, and creating innovations can be done like turning the palm with the presence of technology. This results in students who are in a learning environment with supportive technology that can significantly excel compared to students who do not have access to technology (Mellati \& Khademi, 2018).

Anu Madgavkar, a partner at consulting firm McKinsey, stated that in the future one must embrace and advance technology. Therefore it can be said that technology-based education is considered as something that has a high urgency and its existence is needed for the wider community.

As mentioned before, the existence of digitalization also occurs a disruption for the youth who is struggling to find a job (Blustein et al., 2020). Therefore, this explained technology-based education implemented by PeTIK may help students who need skills in the field of technology and information. 


\subsection{SROI ANALYSIS}

The impact resulting from a program affect the stakeholder of the program itself. Quoting Lombardo et.al, (2019) "SROI methodology describes how change is being created, placing monetary value on that change and thus allowing to measure the value of social outcomes generated by an organization in relation to the relative cost of achieving those outcomes".

Several researches which measure impacts of educational program using SROI as the method has been done a lot in past years. SROI believed to be the most suited method to measure impacts on a program as there are indicators of stakeholder involvement in a program to see the perceived impact of the program. With the involvement of stakeholders, the results of the resulting analysis will then present more comprehensive and implementable data (Purwohedi, 2016).

Furthermore, Purwohedi (2016) stated SROI can measure impact of the programs from three aspects, namely social, environmental, and economic. In its implementation, SROI involves stakeholders to get different impacts obtained from each party. In this research, SROI was used as the method to see if PeTIK has any impacts on the social, environmental, and economic for their stakeholders.

\section{RESEARCH METHOD}

The type of research is qualitative while using primary and secondary data. The primary data is in the form of interviews and observations while the secondary data referred to in this research is in the form of documentation obtained from documents owned by PeTIK.

The method used is Social Return on Investment to see if there is any impact created by PeTIK. There are 6 stages to go through; 1) Establishing scope and identifying stakeholders; 2) Mapping the outcomes; 3) Evidencing outcomes and giving a value; 4) Establishing impact; 5) Calculating the SROI; 6) Reporting and using. Further explanation regarding the stages are explained in the following table.

Table 1. Stage Analysis of SROI

\begin{tabular}{ll}
\hline \multicolumn{1}{c}{ Stage Analysis } & \multicolumn{1}{c}{ Application in Research } \\
\hline & $\begin{array}{l}\text { The object of this study is PeTIK and } \\
\text { the first stage is to identify the } \\
\text { stakeholders which is the party who } \\
\text { affected by the program. In this } \\
\text { research, the stakeholders are } \\
\text { students, alumni, teacher and staff } \\
\text { workers, parents, lastly are the } \\
\text { people in local communities. }\end{array}$ \\
\hline \multirow{2}{*}{ Mapping the Outcome } & $\begin{array}{l}\text { This stage is carried out after } \\
\text { observations and interviews with }\end{array}$ \\
\hline
\end{tabular}




\begin{tabular}{ll}
\hline \multicolumn{1}{c}{ Stage Analysis } & \multicolumn{1}{c}{ Application in Research } \\
\hline & representatives of PeTIK. The \\
& purpose of this stage is to develop an \\
& impact map which is also known as a \\
& theory of change or logic model, \\
& which can show the relationship \\
& between inputs, outputs, and \\
& outcomes. \\
\hline Evidencing Outcomes and Giving a & The next stage is evidencing \\
& outcome and giving the value of the \\
& impacts created by PeTIK. This stage \\
& is done by determining the indicators \\
& of the impacts using financial \\
proxies. & To avoid overestimating the impact \\
created, at this stage the impact will \\
be analyzed further by including \\
several techniques including \\
deadweight, displacement, \\
attribution, and drop-off. \\
There are five steps that must be \\
Therting and Using \\
taken in calculating the SROI \\
starting from projecting the future \\
value, calculating the Net Present \\
Value, calculating the ratio, \\
conducting sensitivity analysis, and \\
calculating the return on investment. \\
All steps can be done manually or by \\
using the help of Microsoft Excel \\
provided by The SROI Network and \\
can be downloaded at \\
www.thesroinetwork.org. \\
The final step of SROI is reporting \\
the results of PeTIK evaluation to \\
stakeholders for further use and \\
implementation in order to increase \\
the effectiveness of the program. \\
\hline
\end{tabular}

\section{FINDINGS AND DISCUSSION}

The discussion in this paper will be based on the six stages of SROI method.

1. Establishing scope and identifying stakeholder 
The first step in conducting an SROI analysis is to determine the scope and identify stakeholders. The stakeholders included in this study are the students, alumni, teachers and staff workers, the parents of the alumni, and also the people in local communities

2. Mapping the outcomes

Mapping of inputs, outputs, and outcomes was carried out after observations and interviews with representatives of PeTIK. The purpose of this stage is to develop an impact map which is also known as a theory of change or logic model.

3. Evidencing outcomes and giving a value

After mapping the inputs and outputs, the next step is the outcome or results related to changes or benefits felt by the stakeholders. For more details, the outcomes will be presented in Table 1.

Table 2. PeTIK's Outcome

\begin{tabular}{ll}
\hline \multicolumn{1}{c}{ Stakeholders } & \multicolumn{1}{c}{ Outcome } \\
\hline Students & Leveling up education \\
\hline Alumni & Scholarship, Increasing income \\
\hline $\begin{array}{l}\text { Teacher and Staff } \\
\text { Workers }\end{array}$ & $\begin{array}{l}\text { Employment opportunities, supporting teacher } \\
\text { and staffs' children education }\end{array}$ \\
\hline Parents & Improving the economic condition for the family \\
\hline $\begin{array}{l}\text { People in local } \\
\text { communities }\end{array}$ & Decreasing poverty \\
\hline
\end{tabular}

Source: Proceed by researcher

4. Establishing impact

After mapping the inputs, outputs, and outcomes, the next step is to give the values to the outcomes or impacts that arise as a result of the PETIK. The scoring is done by determining the indicators of the impact results. Table 3 describes the indicators and also a financial proxy of each impact felt by the stakeholders.

Table 3. The value of PeTIK's outcome

\begin{tabular}{llll}
\hline \multicolumn{1}{c}{ Outcome } & \multicolumn{1}{c}{ Impact } & \multicolumn{1}{c}{ Indicators } & Financial Proxy \\
\hline $\begin{array}{l}49 \text { students get } \\
\text { higher } \\
\text { education and } \\
\text { have their basic } \\
\text { needs fulfilled } \\
\text { for the learning } \\
\text { period }\end{array}$ & $\begin{array}{l}\text { Increasing } \\
\text { education }\end{array}$ & $\begin{array}{l}\text { Completed 1 } \\
\text { year of intensive } \\
\text { education } \\
\text { program }\end{array}$ & $\begin{array}{l}\text { The cost of } \\
\text { education program }\end{array}$ \\
\hline $\begin{array}{l}22 \text { alumni } \\
\text { granted }\end{array}$ & $\begin{array}{l}\text { Increasing } \\
\text { education }\end{array}$ & $\begin{array}{l}\text { Receiving } \\
\text { undergraduate }\end{array}$ & $\begin{array}{l}\text { Tuition fee and } \\
\text { living cost for } 4\end{array}$ \\
\hline
\end{tabular}




\begin{tabular}{llll}
\hline \multicolumn{1}{c}{ Outcome } & \multicolumn{1}{c}{ Impact } & \multicolumn{1}{c}{ Indicators } & \multicolumn{1}{c}{ Financial Proxy } \\
\hline $\begin{array}{l}\text { undergraduate } \\
\text { scholarships } \\
\text { and living } \\
\text { expenses }\end{array}$ & & $\begin{array}{l}\text { scholarship } \\
\text { program }\end{array}$ & years \\
\hline $\begin{array}{l}11 \text { alumni with } \\
\text { a steady income } \\
\text { and better }\end{array}$ & $\begin{array}{l}\text { Increasing } \\
\text { economic status }\end{array}$ & $\begin{array}{l}\text { Income received } \\
\text { by alumni }\end{array}$ & Monthly income \\
\hline $\begin{array}{l}\text { 26 teachers and } \\
\text { staff workers }\end{array}$ & Employment & $\begin{array}{l}\text { Income received } \\
\text { by teacher and } \\
\text { staff workers }\end{array}$ & Salary expenses \\
\hline
\end{tabular}

12 teachers and staff workers who have school-age children who receive subsidy $\begin{array}{ll}\text { Increasing } & \begin{array}{l}\text { Subsidy received } \\ \text { education }\end{array} \\ \text { for child } \\ \text { education }\end{array}$ Subsidy expenses for child education

\begin{tabular}{llll}
\hline $\begin{array}{l}\text { 9 alumni } \\
\begin{array}{l}\text { covering the } \\
\text { living expenses } \\
\text { of the family }\end{array}\end{array}$ & $\begin{array}{l}\text { Improving } \\
\text { economy } \\
\text { condition for } \\
\text { the family }\end{array}$ & $\begin{array}{l}\text { Electricity bills, } \\
\text { daily } \\
\text { consumption } \\
\text { costs, younger } \\
\text { siblings' } \\
\text { education }\end{array}$ & $\begin{array}{l}\text { Monthly expenses } \\
\text { paid }\end{array}$ \\
\hline $\begin{array}{l}\text { 4 Alumni who } \\
\text { regularly pay } \\
\text { zakat profession }\end{array}$ & $\begin{array}{l}\text { Decreasing } \\
\text { poverty }\end{array}$ & $\begin{array}{l}\text { Amount of zakat } \\
\text { profession paid }\end{array}$ & $\begin{array}{l}\text { Zakat profession } \\
\text { paid every month }\end{array}$
\end{tabular}

Source: Proceed by researcher

\section{Calculating SROI}

The SROI ratio is calculated by dividing the Net Present Value of Benefit by the total input. The following is the calculation to get the SROI quotation ratio:

$$
\text { SROI Ratio }=\frac{\text { Net Present Value of Benefit }}{\text { Value of Inputs }}=\frac{R p .5 .536 \cdot 257.626}{R p \cdot 3 \cdot 244.421 .440}=1.7
$$

6. Reporting and using

The last, and most important step in the SROI analysis is reporting, using, and implementing the evaluation results obtained from the SROI analysis. After all the steps are completed, the analysis report on the 
calculation of the PeTIK SROI value is then submitted to the secretariat and general department who are the key informants of this research.

The findings were then reported to YBM PLN as the donor agency for the program. There are several things that will then be carried out by YBM PLN in response to the results of the research report, including:

a. The results of the research will be used as a reference and consideration for YBM PLN as a tool for evaluating the performance of PETIK to increase the impact created

b. There is further information that currently PETIK has been developed in two areas, namely PeTIK I Depok and PETIK II Jombang. However, there is currently no teaching and learning activities in PeTIK II Jombang. Based on the evaluation of the impact of PeTIK I Depok, the results of the research will be used as a reference in the design of the PeTIK II Jombang program to maximize the impact that is expected to be created as the teaching and learning process progresses in the future.

Two points above shows that the results of the SROI analysis can be used as evidence that intervention in education is needed, moreover in this pandemic, to level up the skills of the youth. It also can then be used as a measurement for changes to PeTIK. Key stakeholders such as teachers and employees can communicate to YBM PLN as the main donor for the results of the SROI analysis obtained. This is done to increase the value of the impact arising from the existence of PeTIK as well as a form of accountability to the Muzaki who trust their zakat funds in YBM PLN.

\section{CONCLUSION}

The result shows that the SROI ratio of PeTIK in the time of pandemic is 1.7. Meaning the Rp.1 invested in PeTIK has created an impact on Rp. 1.7. Some of the impacts created are undergraduate scholarship programs for alumni, an increase in education, income, employment opportunities, and children's education, and also a decrease in poverty levels. This shows that PeTIK as an educational program operating using zakat funds is a developed framework to intervene the unemployed problems and can be one of the solutions Indonesia's need in the pandemic.

\section{REFERENCES}

Blustein, D., Duffy, R., Ferreira, J., Cohen-Scali, V., Cinamon, R., \& Allan, B. (2020). Unemployment in the time of COVID-19: A research agenda. Journal of Vocational Behavior, 119(May), 1-4. https://doi.org/10.1016/j.jvb.2020.103436

CNN Indonesia. (2020). Lapangan Kerja Menyempit, 1,8 Juta Lulusan SMA Tak Kuliah. Retrieved March 11, 2020, from 
https://www.cnnindonesia.com/nasional/20200311134223-20-

482440/lapangan-kerja-menyempit-18-juta-lulusan-sma-tak-kuliah

Fasiha, F. (2017). Zakat Produktif. (M. R. Abdullah, Ed.) (I). Makassar: Laskar Perubahan.

Hanik, P., Maharani, S., \& Fadhil, M. (2020). Impact Assessment of the BAZNAS Scholarship Program with the Social Return of Investment. International Journal of Zakat and Islamic Philantrophy, (2018), 5158.

Lombardo, G., Mazzocchetti, A., Rapallo, I., Tayser, N., \& Cincotti, S. (2019). Assessment of the Economic and Social Impact Using SROI: An Application to Sport Companies. Sustainability, 11, 1-21. https://doi.org/10.3390/su11133612

Mellati, M., \& Khademi, M. (2018). Technology-Based Education : Challenges of Blended Educational Technology. IGI Global, (December). https://doi.org/10.4018/978-1-5225-7010-3.ch003

Nurhayati. (2020). Unemployment surges to decade high as COVID-19 causes millions to lose jobs. Retrieved November 5, 2020, from https://www.thejakartapost.com/news/2020/11/05/unemploymentsurges-to-decade-high-as-covid-19-causes-millions-to-lose-jobs.html

Nusapati, A. I., Bahri, E. S., \& Bayinah, A. N. (2020). The Measurement of Social Value Impact of ZISWAF using Social Return on Investment Model at Smart Ekselensia Indonesia. Al-Iqtishad: Journal of Islamic Economics, 12(1), 129-148.

Purwohedi, U. (2016). Social Return on Investment (SROI) Sebuah Teknik untuk Mengukur Manfaat/Dampak dari Sebuah Program atau Proyek (I). Yogyakarta: LeutikaPrio.

Shidiq, S. (2017). Fikih Kontemporer (2nd ed.). Jakarta: Kencana.

Sudrajat, H. R., \& Aisyah, S. (2017). Multiplier Effect of Zakat : Case Study in Tello Island, South Nias, Indonesia on National Amil Zakat Agency Education Program. In Paper Proceedings of the Second Asia-Pacific Conference on Multidisciplinary Research 2017 (APMR2017) (Vol. 2017). Colombo: International Center for Research and Development.

Widiastuti, T., \& Rosyidi, S. (2015). Model Pendayagunaan Zakat Produktif oleh Lembaga Zakat dalam Meningkatkan Pendapatan Mustahiq. Jurnal Ekonomi Dan Bisnis Islam, 1(1), 89-102. 
